Federal Reserve Bank of Dallas

Globalization and Monetary Policy Institute

Working Paper No. 291

http://www.dallasfed.org/assets/documents/institute/wpapers/2016/0291pdf

\title{
Do Oil Endowment and Productivity Matter for Accumulation of International Reserves?*
}

\author{
Rasmus Fatum \\ University of Alberta \\ Guozhong Zhu \\ University of Alberta \\ Wenjie Hui \\ Peking University
}

December 2016

\begin{abstract}
We develop a dynamic stochastic optimization model with oil price shocks to show that countries with certain combinations of oil endowment and productivity have strong precautionary incentives to accumulate foreign reserves in response to oil price shocks. Using the Simulated Method of Moments to estimate the model we demonstrate how oil price shocks are absorbed by changes in foreign reserves which, in turn, leads to less variation in aggregate consumption. Along with productivity and oil endowment, we also consider as determinants of reserves holding conventional variables such as trade-to-GDP ratio and capital openness. Overall, our results suggest that productivity and oil endowment are potentially important determinants of foreign reserves that for some countries should be considered as complements to conventional determinants.
\end{abstract}

JEL codes: E21, F40, Q43

\footnotetext{
* Rasmus Fatum, Alberta School of Business, University of Alberta, Edmonton, Alberta, T6G 2R6, Canada. 780-492-3951. rasmus.fatum@business.ualberta.ca. Guozhong Zhu, University of Alberta, Edmonton, Alberta, T6G 2R6, Canada. guozhong@ualberta.ca. Wenjie Hui, Guanghua School of Management, Peking University. wenjiehui@pku.edu.cn. We thank Jevan Cherniwchan, Kathryn Dominguez and Emilson Silva for helpful discussions. The views in this paper are those of the authors and do not necessarily reflect the views of the Federal Reserve Bank of Dallas or the Federal Reserve System.
} 


\title{
Do Oil Endowment and Productivity Matter for Accumulation of International Reserves?*
}

\author{
Rasmus Fatum ${ }^{\dagger}$ and Guozhong Zhu ${ }^{\ddagger}$ and Wenjie Hui ${ }^{\S}$
}

\begin{abstract}
We develop a dynamic stochastic optimization model with oil price shocks to show that countries with certain combinations of oil endowment and productivity have strong precautionary incentives to accumulate foreign reserves in response to oil price shocks. Using the Simulated Method of Moments to estimate the model we demonstrate how oil price shocks are absorbed by changes in foreign reserves which, in turn, leads to less variation in aggregate consumption. Along with productivity and oil endowment, we also consider as determinants of reserves holding conventional variables such as tradeto-GDP ratio and capital openness. Overall, our results suggest that productivity and oil endowment are potentially important determinants of foreign reserves that for some countries should be considered as complements to conventional determinants.
\end{abstract}

Keywords: foreign reserves, oil price shocks, precautionary demand

\section{Introduction}

We attempt to contribute to the literature on foreign reserves as a precautionary asset by focusing on a particular type of economic shocks - shocks to the price of oil. In doing so

*We thank Jevan Cherniwchan, Kathryn Dominguez and Emilson Silva for helpful discussions.

${ }^{\dagger}$ Corresponding author, School of Business, University of Alberta, rasmus.fatum@ualberta.ca. Fatum is also Research Associate at the Federal Reserve Bank of Dallas and at the University of Copenhagen. Fatum gratefully acknowledges financial support from a Foote Professorship in International Business.

$\ddagger$ School of Business, University of Alberta, guozhong@ualberta.ca

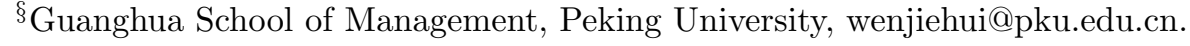


we unveil how oil price shocks may help explain different levels of foreign reserves across countries with different combinations of oil endowment and productivity

The starting point for our study is to observe that countries with high productivity but little oil endowment, countries such as Japan and Switzerland, typically rely heavily on oil imports. By contrast, countries with low productivity but abundant oil endowment, countries such as Russia and Mexico, typically rely heavily on oil exports. These countries can be described as having a poor match between productivity and oil endowment and, ceteris paribus, should be more vulnerable to oil price shocks and, as a result, should accumulate more foreign reserves out of precautionary motives.$^{2}$ By the same token, countries that can be described as having a good match between productivity and oil endowment, i.e. countries with either high productivity and abundant endowment or countries with low productivity and scarce endowment should, ceteris paribus, be less vulnerable to oil price shocks and hence accumulate relatively fewer foreign reserves due to weaker precautionary motives.

We use these observations to motivate and develop a dynamic stochastic optimization model with the following key characteristics. Countries differ in productivity and oil endowment. Oil and labor are the two inputs in production. The price of oil is subject to random shocks, and countries accumulate foreign reserves in order to smooth aggregate consumption against oil price shocks. The resulting model is estimated via the Simulated Method of Moments (SMM). The estimation is facilitated by the partial effects of oil endowment and productivity on the reserves-to-GDP ratio for oil-rich and oil-poor countries, respectively. We obtain these partial effects from fixed effect regressions using panel data of 54 countries spanning the 1993-2003 time period and we include in this regression more traditional

\footnotetext{
${ }^{1}$ The importance of foreign reserves as a precautionary asset for providing insurance against economic shocks has been demonstrated both empirically and theoretically. For recent contributions see, for example, Gourinchas and Obstfeld (2012) and Fogli and Perri (2015).

${ }^{2}$ To illustrate, oil production per person per year across the 2003 to 2013 period is $0.38,0.17,10.40$, and 25.68 barrels for Japan, Switzerland, Mexico and Russia, respectively, while labor productivity (relative to a US benchmark of 100) for these four countries in 2012 is 62.5, 85.9, 29.9, and 37.4, respectively. Moreover, the simple average of foreign reserves-to-GDP ratios across the aforementioned four countries is markedly higher, at 23.83 over the 1993-2013 period, than the average reserves-to-GDP ratio of 15.23 across the remaining 114 countries in our sample. Statistics according to OECD and own calculations.
} 
explanatory variables for reserves accumulation as considered by previous studies ? $^{3}$

Our results suggest that the simulated moments match the partial effects of productivity and oil endowment well. Furthermore, the model quantitatively matches the average reserves-to-GDP ratio and the oil trade pattern observed in the data. The quantitative performance is robust to alternative assumptions regarding interest rate and international borrowing limit. Using the estimated model, we demonstrate how oil price shocks are absorbed by changes in foreign reserves which, in turn, leads to a low(er) coefficient of variation of aggregate consumption.

Using the estimated model, we evaluate the relative importance of precautionary demand for foreign reserves against oil price shocks for 112 economics in the world. We further show how the explanatory power of productivity and oil output for foreign reserves differ across countries. Importantly, our results suggest that the explanatory power of oil endowment and productivity in regards to foreign reserves-to-GDP ratio is so pronounced that for these countries it is insufficient to rely on traditional explanatory variable when analyzing foreign reserves. For countries where foreign reserves are not well explained by productivity and oil output, our results suggest that conventional variables such as trade-to-GDP ratio and capital openness are appropriate predictors of foreign reserves.

The notion of using foreign reserves to smooth consumption is in line with early work by Clark (1970) and Heller (1966) in which the cut of consumption expenditure is seen as the cost of reserve depletion. It is also in line with more recent contributions that emphasize the role of foreign reserves as a buffer against both internal and external economic shocks (e.g. \begin{tabular}{|l|l|l|l|l|}
\hline Durdu 2009, Durdu et al. 2009, Fogli and Perri 2015, Jeanne and Rancière 2011, Mendoza et \\
\hline
\end{tabular} al. 2009). A common characteristic of the modeling approach of existing studies is their use of various shocks that lead to the manifestation of the precautionary savings motive in the form of an adjustment in the holding of reserves. An innovation of our work is to demonstrate that a different type of exogenous shocks, namely oil price shocks, is for certain types of countries an important driver of precautionary demand for foreign reserves and, furthermore, that the relative importance depends on the match between productivity and oil endowment

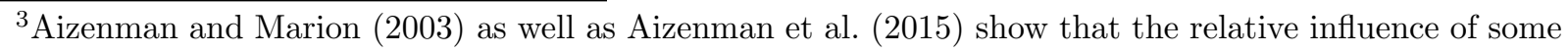
of these more traditional reserves accumulation determinants vary over time.
} 
of a given country. Since our results suggest that the level of foreign reserves (relative to GDP) depends on the match between productivity and oil endowment thus it differs across countries, we also indirectly add to the literature on the optimal level of foreign reserves. $4^{4}$

Overall, our study is novel in proposing that oil price shocks, productivity, and oil endowment matter for holdings of foreign reserves. Importantly, since we find that oil price shocks have a salient effect on foreign reserves only for countries characterized by certain combinations of productivity and oil endowment, we emphasize that while our study offers a new and potentially important complementary insight to the literature on foreign reserves it does not refute any existing insights.

The rest of the paper is organized as follows. Section 2 develops the model and details the mechanisms that relate foreign reserves to oil price shocks, oil endowment and productivity. Section 3 describes the quantitative analysis and the SMM estimation. Section 4 assesses the explanatory power of oil endowment and productivity with respect to the reserves-to-GDP ratio. Section 5 concludes.

\section{The Model}

This section describes a dynamic optimization model in which a country holds foreign reserves to smooth its aggregate consumption in response to oil price shocks.

\section{$2.1 \quad$ Production}

The model is formulated in discrete time with time denoted by subscript $t 5^{5}$ Each country uses two inputs, labor $L_{t}$ and oil $X_{t}$, to produce a final good, $Y_{t}{ }^{6}$ Labor supply is assumed to be inelastic. The production function takes the following Cobb-Douglas form:

$$
Y_{t}=A_{t} X_{t}^{\alpha} L_{t}^{1-\alpha}
$$

\footnotetext{
${ }^{4}$ The seminal work by Triffin (1960) suggests that optimal reserves levels are such that a country should maintain foreign reserves amounting to 20 to 30 percent of total imports.

${ }^{5}$ For simplicity we omit the country subscript $i$ until the quantitative analysis.

${ }^{6}$ In principle, $X_{t}$ represents the composite of all natural resources used in production. However, in light of the importance of oil in modern production and the dramatic oil price volatility, we focus our interpretation of $X_{t}$ on oil in our model description as well as in our quantitative analysis.
} 
where $\alpha<1$ is the share of oil in production and $A_{t}$ is the productivity with respect to the efficiency of converting oil into the final good. Output per capita is thus a power function of oil input per capita:

$$
y_{t}=A_{t} x_{t}^{\alpha}
$$

We abstract from capital for ease of exposition. However, since productivity is assumed to be country-specific, $A_{t}$ can be interpreted as a combination of conventional total factor productivity (TFP) and capital intensity. Productivity is increasing in both TFP and capital intensity, thus industrialized countries exhibit higher productivity in our model.

\subsection{Budget Constraint}

In each period, a country is endowed with $\bar{x}$ units of oil per capita. 7 For a given country, the input of oil $x_{t}$ (referred to as "oil consumption") can be written as

$$
x_{t}=\bar{x}+x_{t}^{i m}
$$

where $i m$ denotes imports. When a country exports oil, $x_{t}^{i m}$ is negative.

In each period, the budget constraint is

$$
\begin{aligned}
c_{t} & =s_{t}-\frac{s_{t+1}}{1+r}+A_{t}\left(\bar{x}+x_{t}^{i m}\right)^{\alpha}-p_{t} x_{t}^{i m} \\
s_{t+1} & \geq \underline{S}
\end{aligned}
$$

where $s_{t}$ is the stock of foreign reserves in period t, $\underline{S} \leq 0$ is the borrowing limit, $p_{t}$ is the price of oil, and $r$ is the interest rate that satisfies

$$
r= \begin{cases}r_{\text {debt }}, & \text { if } s_{t+1}<0 \\ r_{\text {asset }}, & \text { if } s_{t+1} \geq 0\end{cases}
$$

i.e. we allow the borrowing rate to differ from the lending rate.

In this model economy GDP is defined as

$$
G D P=A_{t}\left(\bar{x}+x_{t}^{i m}\right)^{\alpha}-p_{t} x_{t}^{i m}
$$

\footnotetext{
${ }^{7}$ We assume $\bar{x}$ to be time-invariant.
} 
For an oil-importing country, since oil is the intermediate good used in production, $G D P$ is the difference between total final good production and the value of imported oil, $p_{t} x_{t}^{i m}$. Similarly, for an oil-exporting country, GDP is the sum of final good production and oil exports, $-p_{t} x_{t}^{i m}$.

The price of oil is stochastic. In Equation (4), random shocks to $p_{t}$ causes volatility of the $p_{t} x_{t}^{i m}$ term, thereby creating consumption volatility. The change in reserves, $s_{t}-s_{t+1} /(1+r)$, is used as a buffer against such price shocks in order to mitigate consumption volatility. $]^{8}$

The precautionary demand for reserves also depends on a country's borrowing limit $\underline{S}$. The borrowing limit is specified as a fraction of GDP, i.e.

$$
\underline{S}=\underline{s} \times G D P
$$

with $\underline{s} \leq 0$. In the case of $\underline{s}=0$, no borrowing is allowed.

\subsection{The Country's Optimization Problem}

A country, or its representative household, maximizes the discounted sum of expected utility. Let $\beta$ be the discount factor and $E$ be the expectation operator, the optimization problem is

$$
\max _{x_{t}, s_{t+1}} \sum_{t=0}^{\infty} \beta^{t} E u\left(c_{t}\right)
$$

subject to equations (4)- (7). Here $u\left(c_{t}\right)$ is the utility from consuming $c_{t}$ units of final good. The expectation is taken with respect to future consumption which is stochastic due to oil price shocks.

The optimization problem involves both inter-temporal and intra-temporal allocations. Intra-temporally, the country determines how much oil to import/export. Inter-temporally, the country determines the amount of future foreign reserves, $s_{t+1}$, to hold.

When the borrowing constraint is not binding, the first order condition with respect to

\footnotetext{
${ }^{8}$ To illustrate, when oil price is relatively high, oil-importing countries run down reserves to smooth consumption while oil-exporting countries increase their stock of reserves. Reverse operations occur when oil price is relatively low. The persistence of oil price shocks matters in the sense that more persistence implies higher precautionary demand for foreign reserves.
} 
oil imports leads to the following equation:

$$
p_{t}=\alpha A\left(\bar{x}+x_{t}^{i m}\right)^{\alpha-1}
$$

Using oil-importing countries as the example, Equation (9) states that the marginal cost of importing one unit of oil, $p_{t}$, should equal the marginal benefit which is the marginal product of oil.

Equation (9) can be rewritten as

$$
x_{t}^{i m}=\left(\frac{A \alpha}{p_{t}}\right)^{1 /(1-\alpha)}-\bar{x}
$$

thereby illustrating that the reliance of a country on oil imports/exports has three determinants: oil endowment $\bar{x}$, productivity $A$, and oil price $p_{t}$.

An important implication of Equation 10 is that oil-rich countries are not necessarily oil-exporting countries, and vice versa. For example, when oil price is sufficiently high, countries with low oil endowment will be oil exporters. In the quantitative analysis (Section 3 ), we present the data pattern of oil-trading for countries with different combinations of oil endowment and productivity and, in turn, use this pattern along with other data moments to identify the model parameters ${ }^{9}$

When the borrowing constraint is binding, the intra-temporal optimization leads to the following corner solution:

$$
x_{t}^{i m}=\frac{s_{t}-\underline{S}}{p_{t}}
$$

i.e. a given country depletes its reserves and borrows to the limit on the international financial market in order to import oil.

Turning to the inter-temporal part of the optimal allocation problem, foreign reserves for the next period, $s_{t+1}$, are chosen such that the marginal utility of consumption satisfies the following first-order condition:

$$
u^{\prime}\left(c_{t}\right) \geq \beta(1+r) E u^{\prime}\left(c_{t+1}\right)
$$

\footnotetext{
${ }^{9}$ Table A2 shows, not surprisingly, that most oil-rich countries are net exporters of oil while most oil-poor countries are net importers.
} 
which holds as an equality when a country has sufficient foreign reserves. This first-order condition requires the smoothness of consumption across periods, where the smoothness depends on the curvature of the utility function (to be estimated in Section 3).

The precautionary purpose of foreign reserves can be seen from the budget constraint and Equations (10)-(12). For oil-poor countries, the smoothness of consumption depends on the sufficient provision of oil for final good production. Most of the oil-poor countries are oil importers. Among them countries with relatively more oil endowment are less reliant on imports, hence have less demand for reserves, and countries with relatively higher productivity have stronger appetites for and thus reliance on imports, hence higher demand for reserves.

For oil-rich countries, aggregate consumption can partly be funded by proceeds from oil exports, thus foreign reserves serve as the buffer stock against negative oil price shocks. Most of the oil-rich countries are oil exporters. Among them countries with more oil endowment rely more on exports, hence need additional foreign reserves, and countries with higher productivity can instead choose to allocate more oil to the production of final good when oil price is low, thus need fewer foreign reserves.

\subsection{Recursive Representation and Stationarity}

For the quantitative analysis of the next section, it is convenient to rewrite the model recursively. Let $V(s, p, A, \bar{x})$ be the value function defined on the state vector consisting of current foreign reserves $s$, oil price $p$, productivity $A$ and oil endowment $\bar{x}$, it then satisfies the following functional equation:

$$
V(s, p, A, \bar{x})=\max _{s^{\prime}} u(c)+\beta E V\left(s^{\prime}, p^{\prime}, A^{\prime}, \bar{x}\right)
$$

subject to the budget equation (4), the borrowing constraint (5), and the exogenous oil price process (to be specified in the Section 3 . ${ }^{10}$

We adopt the commonly used CRRA utility function:

$$
u(c)=\frac{c^{1-\gamma}}{1-\gamma}
$$

\footnotetext{
${ }^{10}$ Note that subscript $t$ is omitted and $t+1$ is replaced by primes.
} 
where $\gamma$ is the curvature parameter that determines the degree of relative risk aversion of a country.

In reality, productivity increases over time due to, for example, technological progress. This, in turn, endogenously generates non-stationary output, consumption and foreign reserves holdings. Oil price will also be non-stationary if productivity grows over time. Because of the infinite horizon of the model, before the model can be estimated we analytically transform it into a stationary form by re-scaling the affected variables. Appendix A provides details regarding the re-scaling of the variables and the computation of the model.

\section{Quantitative Analysis}

The quantitative analysis is carried out in three steps. First, the partial effects of oil endowment and productivity on foreign reserves are estimated empirically. Next, using these estimated partial effects along with key data moments, the structural model is estimated via the SMM. Third, based on the structural model estimates, the link between oil price and foreign reserve holdings conditional on combinations of oil endowment and productivity is further examined.

\subsection{Partial effects of Oil Endowment and Productivity}

To estimate the partial effects of oil endowment and productivity on the reserves-to-GDP ratio, we run fixed effect regressions using a panel of 54 countries spanning the 1993-2013 time period. As control variables we include an expansive set of variables typically considered as possible determinants of foreign reserves. 11

We use annual oil production per capita to proxy for oil endowment of a country ${ }^{12}$ We split the sample into oil-rich and oil-poor countries according to the median oil consumption in the sample which is 4.58 barrels per capita per year. The split is consistent with the idea that the reliance on oil imports/exports depends on the size and the sign of the gap between

\footnotetext{
${ }^{11}$ Appendix $B$ discusses the data and reports summary statistics in Table A1.

12 This measurement of oil endowment is preferable relative to proven oil reserves because the former reflects oil endowment that is currently available and extractable.
} 
oil endowment and oil consumption (as suggested by Equation (3)).

The following empirical model is estimated for both oil-rich and oil-poor countries:

$$
(\text { Reserves } / G D P)_{i, t}=\theta_{0}+\theta_{1} \times \text { OilOutput }_{i, t}+\theta_{2} \times \text { Productivity }_{i, t}+Z_{i, t} \times \Gamma+\eta_{i}+\epsilon_{i, t}
$$

where $(\text { Reserves } / G D P)_{i, t}$ is the reserves-to-GDP ratio for the $i^{\text {th }}$ country in year $t$ and OilOutput $t_{i, t}$ is the oil output per capita. $Z_{i, t}$ is a set of variables traditionally considered as determinants of foreign reserves, and $\eta_{i}$ is the country fixed effect 13

Productivity $_{i, t}$ is calculated from the time series data on oil consumption and aggregate output for each country separately. The calculation procedure is detailed in Appendix C. The productivity measure has a mean value of 895.4 and a median of 624.2 . Note that traditional measures of productivity, such as the Solow residual or labor productivity as calculated by the OECD, do not treat natural resources as an input in production, hence they are not applicable to our context.

The variables in $Z_{i, t}$ include those related to a country's trade dependence, internal and external economic conditions, capital openness, and exchange rate volatility. Three traderelated measures are included in the regressions - the ratios of total trade, imports, and agricultural imports to GDP, respectively. To capture the influence of a country's internal and external economic conditions we include in our regressions GDP growth rate, $M_{2}$-toGDP ratio, FDI-to-GDP ratio, short-term debt, the Chinn-Ito index (as a proxy for the degree of capital openness), and export volatility. ${ }^{14}$

Table 1 reports the regression results. Among oil-poor countries, oil production has a significantly negative effect on foreign reserves. An increase in oil production by 1 barrel per person per year is associated with a decrease in the reserves-to-GDP ratio by $2.46 \%$. By contrast a productivity increase of 1 unit (i.e. $0.112 \%$ of the mean value of productivity) is associated with a reserves-to-GDP ratio increase of $0.008 \%$. Both effects are statistically

\footnotetext{
${ }^{13}$ We use the reserves-to-GDP ratio rather than the reserves level to control for scale effects. The transaction motive for holding foreign reserves, as noted in Eaton and Gersovitz (1980) and Edwards (1984), suggests that bigger economies need more foreign reserves. For similar reasons, covariates such as trade and money supply are all measured relative to GDP.

${ }^{14}$ The Chinn-Ito index was introduced by Chinn and Ito (2006), and is available at http://web.pdx.edu/ ito/Chinn-Ito_website.htm.
} 
significant.

Among oil-rich countries, the effects of oil production and productivity on the reservesto-GDP ratio are also significant, but the signs are changed. More specifically, an increase in oil production by 1 barrel per person per year is associated with an increase in the reserves-to-GDP ratio of $0.4 \%$. This effect is smaller (in absolute terms) than that of the oil-poor countries. Similarly, a productivity increase of 1 unit is associated with a decrease in the reserves-to-GDP ratio of $0.048 \%$, i.e. for oil-rich countries, productivity has a stronger partial effect on the reserves-to-GDP ratio compared to that of oil-poor countries (in absolute terms).

These partial effects, denoted $\theta_{\text {OilOutput }}($ oilpoor $), \theta_{\text {Productivity }}($ oilpoor $), \theta_{\text {OilOutput }}($ oilrich), and $\theta_{\text {Productivity }}($ oilrich), respectively, are the main moments used to identify the parameters of the structural model.

The regression coefficient estimates of other covariates are unsurprising and generally consistent with standard theories.

\subsection{SMM Estimation}

We use the SMM to estimate the set of parameters $(\beta, \gamma, \underline{s})$ in the structural model. The importance of $\beta$ and $\gamma$ is well understood in the precautionary savings literature ${ }^{15}$ Clearly, borrowing capacity $\underline{s}$ is also important. Intuitively, if borrowing capacity is sufficiently large, a country can always resort to borrowing to keep its consumption smooth and, hence, would need less foreign reserves 16

\subsubsection{Estimation Procedure}

To implement the SMM, we define the distance between model moments and data moments as follows:

$$
£=\left(M_{\text {model }}-M_{\text {data }}\right)^{T} \times W \times\left(M_{\text {model }}-M_{\text {data }}\right)
$$

\footnotetext{
${ }^{15}$ See, for example, Carroll (1997) and Carroll and Samwick (1997).

${ }^{16}$ In the extreme case of unlimited borrowing, a country can continuously rely on borrowing to smooth consumption, thereby eliminating the precautionary demand for foreign reserves.
} 
where $M_{\text {model }}$ and $M_{\text {data }}$ are column vectors of model moments and data moments, respectively, and $\mathrm{W}$ denotes the weighting matrix which is the inverse of the variance matrix of the data moments.

We repeat the following standard procedure until the distance is minimized: (1) Choose a set of values for $(\beta, \gamma, \underline{s})$, and solve for the policy functions of the dynamic programming problem as specified in section 2.4. (2) Use the policy functions to generate time series of reserves, oil imports, consumption, and final good; (3) Compute model moments from the simulated data. (4) Calculate the distance between model moments and data moments. ${ }^{17}$

Seven moments are are used to identify the parameters of interest $(\beta, \gamma, \underline{s})$. These moments are reported in column (1) of Table 2 along with their standard errors.

The first moment is the average reserves-to-GDP ratio. This moment is informative on $\gamma$, since a larger $\gamma$ leads to stronger precautionary demand for foreign reserves. The moment is also informative on $\underline{s}$ since, ceteris paribus, a larger borrowing capacity is associated with a smaller reserves-to-GDP ratio (and vice versa).

The second and third moments pertain to the oil trade pattern in the data. As Table 2 shows, the estimated fraction of oil-poor countries that import oil, Prob(import|oilpoor), is 0.89, while the estimated the fraction of oil-rich countries that import oil, Prob(export|oilrich), is 0.92. As shown in Equation (9)-(10), given a country's productivity and oil endowment, oil trade depends on oil price, foreign reserves holdings and borrowing limit, hence oil trade pattern is itself a function of our structural parameters.

The remaining four moments are $\theta_{\text {OilOutput }}($ oilpoor $), \theta_{\text {Productivity }}($ oilpoor $), \theta_{\text {OilOutput }}($ oilrich), $\theta_{\text {Productivity }}($ oilrich). The data moments are estimated in section 3.1. The corresponding model moments are estimated using the simulated data. Specifically, countries are split into oil-poor and oil-rich groups as per their oil output. For each group the reserves-to-GDP ratio is calculated based on the simulated data and, subsequently, regressed on oil output and productivity to obtain the partial effects. Results of these regressions are obviously sensitive to the values of structural parameters.

We use the inverse of the variance matrix of the data moments as our weighting matrix.

\footnotetext{
${ }^{17}$ Note that to implement step (2) we need to simulate a time series of oil price according to the stochastic property of oil price data which is specified in Section 3.2 .2 .
} 
This diagonal matrix puts more weight on moments with smaller standard deviations. It is efficient since moments with more precise measurement are emphasized. Asymptotically the distance metric $£$ follows a $\chi^{2}$ distribution with four degrees of freedom (7 moments minus 3 parameters).

\subsubsection{Calibrated Parameters}

We calibrate directly from the data a number of parameters and exogenous processes to be used in the structural estimation.

The share of oil in production, $\alpha$, is set to 0.265 . This is based on the relation between output growth and crude oil consumption growth across major economics, as described in Appendix C.

The return on foreign reserves is assumed to be $r_{a s s e t}=0.02$. This is roughly consistent with the average return of the set of assets commonly used as foreign reserves detailed in Appendix $\mathrm{D}^{18}$

Interest rates on international borrowing, $r_{d e b t}$, is set to 0.05 . This is defined as the real interest rate associated with sovereign international borrowing. To ensure robustness of our findings we also implement alternative borrowing rates of 0.075 and 0.10 , respectively. The quantitative results are very similar regardless of choice of borrowing rate.

Oil price is assumed to be exogenous, and described by an $\mathrm{AR}(1)$ process:

$$
\log p_{t+1}=\rho \log p_{t}+\epsilon_{t+1}
$$

where $\epsilon_{t+1}$ is the random shock drawn from a normal distribution.

Since one period in the model corresponds to one year, the process is estimated using annual oil price between 1981-2014, based on the price index of crude petroleum which is the equally weighted average of UK Brent (light), Dubai (medium) and Texas (heavy) 19 The persistence parameter $\rho$ and the standard deviation of $\epsilon$ are 0.730 and 0.217 , respectively. The process is approximated with a three-state first-order Markov chain using the discretization procedure developed in George and Hussey (1991). Specifically, $p_{t}$ has three states: (40.16,

\footnotetext{
${ }^{18}$ Following Heller (1966), the low return on foreign reserve assets is considered the cost of holding reserves.

${ }^{19}$ Additional details are provided in Appendix B
} 
$62.00,95.71) 20$ Correspondingly, the transition probability matrix is

$$
\text { Prob. }=\left(\begin{array}{ccc}
0.6558 & 0.3181 & 0.0261 \\
0.2207 & 0.5586 & 0.2207 \\
0.0261 & 0.3181 & 0.6558
\end{array}\right) \text {. }
$$

\subsubsection{Estimation Results}

The parameter estimates and their standard errors are reported in Table 3 . As the first column of the table shows, the (annual) discount factor and the coefficient of risk aversion are estimated to be 0.977 and 1.646, respectively. These estimates are well within the normal range ${ }^{21}$ The borrowing limit estimate is $\underline{s}=-0.599$, i.e. the model performs the best if each country is allowed to borrow up to about $60 \%$ of its respective GDP. While the estimates of $\beta$ and $\gamma$ are statistically significant, the estimate of $\underline{s}$ is insignificant. The insignificance of the borrowing limit is less surprising considering that the borrowing constraint is rarely hit in the simulated data and, consequently, difficult to identify.

To assess the sensitivity of the model with respect to borrowing capacity, we subsequently set $\underline{s}=-0.4$ (denoted "tight credit") and $\underline{s}=-0.8$ (denoted "loose credit"), respectively, and re-estimate the model. These re-estimation results are also reported in Table 3 . As the table shows, the alternative estimates of $\beta$ and $\gamma$ are very similar to those of the baseline estimation.

The distance between model and data moments, $£$, is 0.809 for the baseline estimation. With four degrees of freedom, the p-value (i.e. $\operatorname{prob}\left(\chi^{2}(4)<0.809\right)$ is 0.06 . Thus the model moments are close to the data moments and at the $10 \%$ level the model is not rejected. The distance is 0.944 and 1.019, respectively, for the alternative borrowing capacities of $\underline{s}=-0.4$ and $\underline{s}=-0.8$. With $\underline{s}$ pre-set, the degree of freedom becomes five instead of four. The associated p-values of 0.03 and 0.04 , respectively, imply that the model is not rejected at the $5 \%$ level. Clearly, the estimated model fits the data well.

Table 3 also reports parameter estimates obtained after the real borrowing rate is set

\footnotetext{
${ }^{20}$ The average oil price of 62 dollars per barrel is in terms of 2006 US dollars, calculated from our sample in the 2000-2014 period.

${ }^{21}$ See, for example, Hansen and Singleton $(1982)$ and Attanasio and Low $(2004)$.
} 
at $7.5 \%$ and $10 \%$ (instead of the baseline rate of $5 \%$ ). The distance becomes 0.840 and 0.901, respectively. Thus the fit is slightly worsened when the borrowing rate is higher. Importantly, in neither case do we reject the model at the $10 \%$ level. The estimated $\beta$ and $\gamma$ are close to those of the baseline estimation. When borrowing rate is higher, the estimated $\underline{s}$ is larger in absolute terms. Intuitively, a higher borrowing rate would encourage more reserves holdings, which is offset by the larger borrowing limit, thereby ensuring that the average reserves-to-GDP ratio from the model matches that in the data. 22

Comparing the model moments (displayed in columns (2)-(6) of Table 2 ) to those in the data, it is of particular interest to note that the coefficients stemming from regressing the reserves-to-GDP ratio on oil output and productivity closely match those in the data. This is the case for both oil-rich and oil-poor countries. This is important as it illustrates that the structural model is able to capture the "true" partial effects of oil output and productivity on the reserves-to-GDP ratio.

\subsection{Foreign Reserves and Oil Price Shocks}

To further investigate the link between oil price shocks and foreign reserves conditional on productivity and oil output, we revisit the persistence of oil price shocks, as captured by the parameter $\rho$ in Equation (17). The estimate for $\rho$ is 0.730 , as noted earlier, implying that it takes about 10 years for an oil price shock to completely phase out.

Due to the strength of persistence, when a positive oil price shock occurs, oil-poor countries turn to the use of foreign reserves to smooth consumption for a lengthy period of time. Inevitably this entails accumulation of sufficiently sizable foreign reserves during times of low oil prices. Similarly, oil-rich countries accumulate sufficient reserves during times of relatively high oil prices in light of the persistence of oil price shocks. We demonstrate these optimization behaviors by examining policy functions regarding foreign reserves accumulation. In turn, we investigate the effectiveness of consumption smoothing by assessing the volatility of oil price, foreign reserves and consumption of countries.

To facilitate this part of our investigation we focus on the four possible oil endowment-

\footnotetext{
${ }^{22}$ With the larger (in absolute terms) estimates of $\underline{s}$ come large standard errors, because the borrowing limit is less likely to be reached when more borrowing is allowed.
} 
productivity combinations: oil-poor and low productivity, oil-poor and high productivity, oil-rich and low productivity, and oil-rich and high productivity. As representatives of these four combinations, we consider the following oil output and productivity pairs: $(1,500)$, $(1,1200),(30,500)$ and $(30,1200)$, where oil output has a mean value of 6.82 barrel per person per year and productivity has a mean value of 895.4 across countries.

\subsubsection{Policy Functions}

The policy functions are depicted in Figure 1. The solid lines represent the optimal levels of foreign reserves as a function of existing reserves given a certain oil price 23 The intersection of a solid line and a dashed line (the 45-degree line) represents the steady state level of foreign reserves to which the economy will converge if oil price is maintained at the given level for sufficiently long.

Figure 1 has four rows of sub-figures where each row represents a combination of productivity and oil output. The first row pertains to countries with low productivity and low oil output. For these countries, the first sub-figure shows that when oil price is low, the steady state of reserves is at approximately 150 USD per capita 24 This steady state level can be interpreted as the optimal amount of reserves saved during "good" times in preparation for "bad" times. When oil price is at a median level (second sub-figure), the steady state of foreign reserves is markedly reduced. Further, foreign reserves are near zero when oil price is high (third sub-figure).

The second row shows policy functions for oil-poor and high productivity countries. The overall pattern is quite similar to that of the first row, i.e. foreign reserves are maintained at relatively high levels when oil price is low thus allowing for their depletion when oil price is high. However, compared to the sub-figures in the first row, the steady state foreign reserves are now much higher (about 900 USD per capita) when oil price is low, and much lower (about -150 USD per capita) when oil price is high, consistent with the suggestion

\footnotetext{
${ }^{23}$ The solid lines are kinked around the origin due to the difference in borrowing and lending rates.

${ }^{24}$ This is in terms of 2006 USD, since we have used the average oil price of 2006 USD as an exogenous input in the model. In addition, in estimating the country-specific productivity, we have used GDP in terms of 2006 USD.
} 
that precautionary motives are more pronounced for high productivity countries with low oil endowment.

Interestingly, policy functions for oil-rich countries, as shown in the last two rows, are markedly different. These policy functions pertain to mainly oil-exporters whose "bad" times occur when oil price is low. Therefore, these countries accumulate reserves when oil price is high, but deplete reserves (or borrow) when oil price is low. Comparing the third row with the fourth row, it is apparent that oil-rich countries with low productivity hold substantially more reserves than oil-rich countries with high productivity. This is consistent with a stronger reliance on oil-exports of the former. It is also noteworthy that when oil price is low, only oil-rich countries associated with low productivity reach the borrowing constraint (left sub-figure of the third row), i.e. the two lines would intersect only if more borrowing is allowed.

\subsubsection{Volatilities}

We also consider how oil price volatility translates into the volatilities of imports/exports, foreign reserves, final good production and consumption, respectively. To do so we simulate a time series of the oil price based on the oil price process described by Equation (17). Incorporating this exogenous oil price series into the model we then simulate the time series of the endogenous variables for each of the four types of countries and, in turn, calculate the coefficient of variation (cv) for each variable of interest.25

Table 4 reports the results. For each of the four country types, the cv of foreign reserves is significantly higher than that of the oil price, while the cv of consumption is much smaller. This is an interesting finding as it is consistent with the presence of a strong buffer effect of foreign reserves against vis-a-vis oil price fluctuations.

\footnotetext{
${ }^{25}$ Each time series encompasses 1000 periods. To ensure stationarity of the series, only the last 500 periods are used in the calculation of the coefficient of variation.
} 


\section{Explanatory Power of Oil Output and Productivity}

In this section we assess the explanatory power of oil output and productivity with respect to foreign reserves. For this assessment we employ data spanning 112 countries over the period of 2003-2013, and obtain the time-series averages of their respective reserves-to-GDP ratios, oil output and productivity ${ }^{26}$ For each country, we then use the structural model to predict its reserves-to-GDP ratio and, in turn, compare the model-implied reserves-to-GDP ratio to the actual reserves-to-GDP ratio as per the data.

We measure the gap between model ratio and data ratio as follows:

$$
g a p=\left|\frac{\text { ratio }^{\text {model }}-\text { ratio }^{\text {data }}}{\text { ratio }^{\text {data }}}\right|
$$

i.e. the gap is defined as the the absolute value of the percentage deviation of the model ratio from the data ratio.

Tables 5 - 6 report the gap for each of the 112 countries. As the tables show, for some countries, such as Russia and Tanzania, the model ratio is almost identical to the data ratio, with the gap well below 0.05, while for other countries, such as Luxembourg and Ireland, the model ratio is far off with the gap exceeding 10 .

The distribution of the 112 countries according to the gaps is reported in Table 7. As the table shows, for about half of the countries the gap is less than 0.75 . In fact, for $13.4 \%$ of the countries the gap is less than 0.25. Thus, for these countries the explanatory power of oil endowment and productivity in regards to foreign reserves is particularly strong.

On the one hand, the gap metric lends credence to the suggestion that the explanatory power of oil endowment and productivity in regards to the reserves-to-GDP ratio for some countries is so pronounced that it is for these countries insufficient to rely on only traditional explanatory variables when analyzing foreign reserves. On the other hand, the results of the gap analysis also imply that oil endowment and productivity have only limited explanatory power for other countries, thereby raising the question of whether the reserves-to-GDP ratio is then for these countries well-explained by the traditional covariates included in the fixed effect regressions of Section 3.1 .

\footnotetext{
${ }^{26}$ Compared to the sample used in the panel regression, this sample has more countries but spans a shorter time period, thereby allowing for the inclusion of countries where data are only available in more recent years.
} 
To address this question, we separate countries and observations into six groups ranked according to the gap metric given by Equation (18). Subsequently, we run the following residual regression for each one of the six groups of countries:

$$
(\text { Reserves } / G D P)_{i, t}^{\text {data }}-(\text { Reserves } / G D P)_{i, t}^{\text {model }}=\alpha_{0}+Z_{i, t} \times \Theta+\zeta_{i, t}
$$

where the left side is the difference in the reserves-to-GDP ratio between the model and the data. The regressors, $Z_{i, t}$, is same the set of covariates used in the fixed effect regressions as specified in Equation (15).

Table 8 summarizes the explanatory power of $Z_{i, t}$ measured by R-squared and adjusted R-squared for each group separately. Clearly, for countries where oil endowment and productivity have lower explanatory power (i.e. countries with larger gaps), the more conventional covariates have better explanatory power. More specifically, for countries with gap > 3 , R-squared and adjusted R-squared are 0.892 and 0.837, respectively. By contrast, for countries with gap $\leq 0.25$, R-squared and adjusted R-squared are 0.321 and 0.050, respectively. Evidently, oil endowment and productivity complement other covariates in explaining the cross-country variation in the reserves-to-GDP ratio.

Table 9 reports the coefficients of the residual regressions. Moving from low gap groups to high gap groups, more coefficients become statistically significant, thereby illustrating the increasing importance of more conventional covariates. This further supports the suggestion that more conventional determinants of foreign reserves, such as trade-to-GDP ratio, capital openness and export volatility, are noticeably more important for countries where oil output and productivity have relatively lower explanatory power with respect to foreign reservesto-GDP ratio.

\section{Conclusion}

We attempt to contribute to the literature on foreign reserves by proposing a dynamic stochastic optimization model in which the price of oil is subject to random shocks and countries accumulate foreign reserves in order to smooth aggregate consumption against such shocks. Our model is estimated via the Simulated Method of Moments, facilitated by 
the partial effects of oil endowment and productivity on foreign reserves-to-GDP ratio for oil-rich and oil-poor countries, respectively. We obtain these partial effects from fixed effect regressions using panel data spanning 54 countries over the 1993-2013 time period and include in the regressions conventional explanatory variables for foreign reserves accumulation considered by previous studies.

Our results suggest that the simulated moments match the partial effects of productivity and oil endowment well. Furthermore, the model quantitatively matches the average foreign reserves-to-GDP ratio and the oil trade pattern observed in the data. Using the estimated model, we demonstrate how oil price shocks are absorbed by changes in foreign reserves which, in turn, lead to reduced variation in aggregate consumption.

Using the estimated model we evaluate the relative importance of precautionary demand for foreign reserves against oil price shocks for 112 countries. Further, we show how the explanatory power of productivity and oil endowment with respect to foreign reserves for several countries is so pronounced that for these countries it is insufficient to rely on conventional explanatory variables when analyzing foreign reserves. We also show that for countries where foreign reserves are not well explained by productivity and oil endowment, conventional variables such as trade-to-GDP ratio and capital openness are better predictors of foreign reserves.

Overall, our study is novel in suggesting that productivity and oil endowment are potentially important determinants of foreign reserves that for some countries should be considered as complements to conventional determinants. 


\section{References}

Aizenman, Joshua and Nancy Marion, "The high demand for international reserves in the Far East: What is going on?," Journal of the Japanese and International Economies, 2003, $17(3), 370-400$.

_, Yin-Wong Cheung, and Hiro Ito, "International reserves before and after the global crisis: Is there no end to hoarding?," Journal of International Money and Finance, 2015, $52(\mathrm{C}), 102-126$.

Attanasio, Orazio P. and Hamish Low, "Estimating Euler equations," Review of Economic Dynamics, 2004, 7 (2), 406-435.

Carroll, Christopher, "Buffer-Stock Saving and the Life Cycle/Permanent Income Hypothesis," The Quarterly Journal of Economics, 1997, 112 (1), 1-55.

- and Andrew A. Samwick, "The nature of precautionary wealth," Journal of Monetary Economics, 1997, 40 (1), 41-71.

Chinn, Menzie D. and Hiro Ito, "What matters for financial development? Capital controls, institutions, and interactions," Journal of Development Economics, 2006, 81 (1), $163-192$.

Clark, Peter Barton, "Optimum International Reserves and the Speed of Adjustment," Journal of Political Economy, 1970, 78 (2), 356-376.

Durdu, Ceyhun Bora, "Quantitative implications of indexed bonds in small open economies," Journal of Economic Dynamics and Control, 2009, 33 (4), 883-902.

_, Enrique G. Mendoza, and Marco E. Terrones, "Precautionary Demand for Foreign Assets in Sudden Stop Economies: an Assessment of the New Mercantilism," Journal of Development Economics, 2009, 89 (2), 194-209.

Eaton, Jonathan and Mark Gersovitz, "LDC participation in international financial markets : Debt and reserves," Journal of Development Economics, 1980, 7 (1), 3-21. 
Edwards, Sebastian, "The Demand for International Reserves and Monetary Equilibrium: Some Evidence from Developing Countries," The Review of Economics and Statistics, 1984, 66 (3), 495-500.

Fogli, Alessandra and Fabrizio Perri, "Macroeconomic volatility and external imbalances," Journal of Monetary Economics, 2015, 69 (C), 1-15.

George, Tauchen and Robert Hussey, "Quadrature-Based Methods for Obtaining Approximate Solutions to Nonlinear Asset Pricing Models," Econometrica, 1991, 59 (2), $317-396$.

Gourinchas, Pierre-Olivier and Maurice Obstfeld, "Stories of the Twentieth Century for the Twenty-First," American Economic Journal: Macroeconomics, 2012, 4 (1), 226265.

Hansen, Lars and Kenneth Singleton, "Generalized Instrumental Variables Estimation of Nonlinear Rational Expectations Models," Econometrica, 1982, 91, 1269-1286.

Heller, H. Robert, "Optimal International Reserves," Econometrica, 1966, 76 (302), 296311.

Jeanne, Olivier and Romain Rancière, "The Optimal Level of International Reserves For Emerging Market Countries: A New Formula and Some Applications," The Economic Journal, 2011, 121 (555), 905-930.

Mendoza, Enrique G., Vincenzo Quadrini, and Jose-Victor Rios-Rull, "Financial Integration, Financial Development, and Global Imbalances," Journal of Political Economy, 2009, $117(3), 371-416$.

Triffin, Robert, Gold and the Dollar Crisis, Yale University Press, 1960. 
Table 1: Determinants of Reserves/GDP

\begin{tabular}{|c|c|c|c|c|}
\hline & \multicolumn{2}{|c|}{ Oil-poor Countries } & \multicolumn{2}{|c|}{ Oil-rich Countries } \\
\hline Oil Output & $\begin{array}{l}\text { Coef. } \\
\mathbf{- 2 . 4 5 8}\end{array}$ & $\begin{array}{l}\text { Std. Err. } \\
\mathbf{( 1 . 0 8 6 )}\end{array}$ & $\begin{array}{r}\text { Coef. } \\
\mathbf{0 . 4 0 1}\end{array}$ & $\begin{array}{l}\text { Std. Err. } \\
(\mathbf{0 . 1 3 8 )}\end{array}$ \\
\hline Productivity & 0.008 & $(0.004)$ & -0.048 & $(0.018)$ \\
\hline Trade/GDP & 0.188 & $(0.066$ & 0.101 & $(0.202)$ \\
\hline Import/GDP & -0.218 & $(0.133)$ & 0.138 & $(0.342)$ \\
\hline Short-debt/GDP & 0.018 & $(0.008)$ & -0.133 & $(0.101)$ \\
\hline Capital Openness & -5.279 & $(1.745)$ & -13.196 & $(5.244)$ \\
\hline FDI/GDP & 0.037 & 0.020 & $(0.211)$ & $(0.099)$ \\
\hline $\mathrm{M} 2 / \mathrm{GDP}$ & 0.046 & 0.020 & $(0.308)$ & $(0.129)$ \\
\hline FX Volatility & -0.023 & $(0.132)$ & -0.708 & $(0.320)$ \\
\hline GDP Growth & 0.158 & $(0.097)$ & -0.348 & $(0.231)$ \\
\hline Export Volatility & 0.652 & $(0.169)$ & -1.020 & $(0.629)$ \\
\hline Agri-imports/GDP & -0.955 & $(0.425)$ & -4.735 & $(1.523)$ \\
\hline 1995 & 0.810 & $(2.161)$ & -3.923 & $(5.184)$ \\
\hline 1996 & -1.280 & $(2.239)$ & -3.680 & $(5.260)$ \\
\hline 1997 & 0.747 & $(2.289)$ & -1.649 & $(5.416)$ \\
\hline 1998 & 1.280 & $(2.083)$ & -0.623 & $(5.551)$ \\
\hline 1999 & 2.970 & $(1.981)$ & -3.626 & $(5.661)$ \\
\hline 2000 & 2.436 & $(1.962)$ & -4.159 & $(5.841)$ \\
\hline 2001 & 3.669 & $(1.955)$ & -2.836 & $(5.692)$ \\
\hline 2002 & 6.246 & $(1.910)$ & -0.692 & $(5.446)$ \\
\hline 2003 & 7.565 & $(1.866)$ & 1.044 & $(5.179)$ \\
\hline 2004 & 6.913 & $(1.879)$ & 5.961 & $(5.449)$ \\
\hline 2005 & 6.173 & (1.908) & 4.276 & $(5.422)$ \\
\hline 2006 & 6.196 & (1.973) & 6.879 & $(5.755)$ \\
\hline 2007 & 6.353 & $(2.015)$ & 10.884 & $(5.748)$ \\
\hline 2008 & 5.819 & $(2.029)$ & 11.780 & $(5.519)$ \\
\hline 2009 & 10.526 & $(2.096)$ & 12.226 & $(5.943)$ \\
\hline 2010 & 9.835 & $(2.044)$ & 10.577 & $(6.010)$ \\
\hline 2011 & 8.986 & $(2.084)$ & 11.195 & $(6.160)$ \\
\hline 2012 & 9.487 & $(2.142)$ & 11.820 & $(6.545)$ \\
\hline 2013 & 8.703 & $(2.178)$ & 13.950 & $(6.960)$ \\
\hline Constant & -5.678 & $(4.181)$ & 43.049 & $(17.208)$ \\
\hline
\end{tabular}

The table reports results from fixed effect regressions. Standard errors are reported in the parenthesis. 
Table 2: Data and Model Moments

\begin{tabular}{l|cc|ccccc}
\hline \hline \multirow{2}{*}{ Moments } & \multicolumn{2}{|c|}{$\begin{array}{c}\text { Data (Std.Err.) } \\
(1)\end{array}$} & $\begin{array}{c}\text { Baseline } \\
\text { Model }\end{array}$ & $\begin{array}{c}\text { Tight } \\
\text { Credit }\end{array}$ & $\begin{array}{c}\text { Loose } \\
\text { Credit }\end{array}$ & $\begin{array}{c}r_{\text {debt }} \\
=7.5 \%\end{array}$ & $\begin{array}{c}r_{\text {debt }} \\
=10 \%\end{array}$ \\
\hline Reserves/GDP & 15.23 & $(2.15)$ & 15.90 & 15.61 & 15.76 & 15.83 & 15.86 \\
Prob(import|oilpoor) & 0.89 & $(0.28)$ & 0.896 & 0.896 & 0.896 & 0.896 & 0.896 \\
Prob(export|oilrich) & 0.92 & $(0.30)$ & 0.943 & 0.943 & 0.943 & 0.943 & 0.943 \\
$\theta_{\text {OilOutput }}$ (oilpoor) & -2.458 & $(1.09)$ & -2.620 & -2.368 & -2.940 & -2.730 & -2.538 \\
$\theta_{\text {Oiloutput }}$ (oilrich) & 0.401 & $(0.14)$ & 0.382 & 0.409 & 0.354 & 0.392 & 0.414 \\
$\theta_{\text {Productivity }}$ (oilpoor) & 0.008 & $(0.004)$ & 0.005 & 0.005 & 0.006 & 0.005 & 0.005 \\
$\theta_{\text {Productivity }}$ (oilrich) & -0.479 & $(0.02)$ & -0.041 & -0.041 & -0.039 & -0.040 & -0.041 \\
\hline \hline
\end{tabular}

This table reports moments from the data and from five versions of the model. The baseline model estimate the borrowing limit $\underline{s}$ along with other parameters. The "Tight Credit" and "Loose Credit" models set $\underline{s}=-0.40$ and $\underline{s}=-0.80$ respectively. Borrowing rate is set to $r_{d e b t}=5 \%$ except in column (5)-(6) where the rate is stated in the header. 
Table 3: Parameter Estimates

\begin{tabular}{|c|c|c|c|c|c|}
\hline & $\begin{array}{l}\text { Baseline } \\
\text { Model }\end{array}$ & $\begin{array}{l}\text { Tight } \\
\text { Credit }\end{array}$ & $\begin{array}{l}\text { Loose } \\
\text { Credit }\end{array}$ & $\begin{array}{c}r_{\text {debt }} \\
=7.5 \%\end{array}$ & $\begin{array}{c}r_{\text {debt }} \\
=10 \%\end{array}$ \\
\hline \multirow[t]{2}{*}{$\beta$} & 0.977 & 0.977 & 0.978 & 0.979 & 0.978 \\
\hline & $(0.009)$ & $(0.007)$ & $(0.012)$ & $(0.009)$ & $(0.015)$ \\
\hline & 1.646 & 1.675 & 1.701 & 1.913 & 2.049 \\
\hline & $(0.321)$ & $(0.395)$ & $(0.641)$ & $(0.473)$ & $(0.857)$ \\
\hline \multirow[t]{2}{*}{$\underline{\underline{-}}$} & -0.599 & -0.40 & -0.80 & -0.671 & -0.788 \\
\hline & $(0.331)$ & (n.a.) & (n.a.) & $(2.864)$ & $(3.457)$ \\
\hline$£$ & 0.809 & 0.944 & 1.019 & 0.840 & 0.901 \\
\hline d.f. & 4 & 5 & 5 & 4 & 4 \\
\hline$p$-value & 0.06 & 0.03 & 0.04 & 0.07 & 0.08 \\
\hline
\end{tabular}

This table reports model parameters estimated via SMM. Standard errors are reported in parenthesis. $£$ denotes the distance between model and data moments which follows a $\chi^{2}$ distribution with degrees of freedom given in the d.f. row. The "Tight Credit" and "Loose Credit" cases set $\underline{s}=-0.40$ and $\underline{s}=-0.80$ respectively, and estimate the remaining two parameters.

Table 4: Country Level Volatilities

\begin{tabular}{cc|ccccc}
\hline \hline & & \multicolumn{5}{|c}{ Coefficient of Variation } \\
Oil Output & Productivity & oil-price & imports & reserves & GDP & consumption \\
\hline 1 & 500 & 0.326 & 0.351 & 1.424 & 0.054 & 0.032 \\
1 & 1200 & 0.326 & 0.083 & 1.345 & 0.084 & 0.041 \\
30 & 500 & 0.326 & 0.134 & 1.458 & 0.238 & 0.213 \\
39 & 1200 & 0.326 & 0.349 & 1.465 & 0.134 & 0.190 \\
\hline \hline
\end{tabular}

This table reports coefficients of variation for four economies, representing the four pairs of (oil-poor, low productivity), (oil-poor, high productivity), (oil-rich, low productivity) and (oil-rich, high productivity), respectively. 
Table 5: Countries by Explanatory Power of Productivity and Oil Output

\begin{tabular}{|c|c|c|c|c|c|}
\hline & Oil per cap & Productivity & $\begin{array}{c}\text { Reserves } / G D P \\
(\text { data }, \%)\end{array}$ & $\begin{array}{c}\text { Reserves } / G D P \\
(\text { model }, \%)\end{array}$ & Gap \\
\hline Russian Federation & 25.68 & 745.13 & 28.29 & 28.83 & 0.02 \\
\hline Tanzania & 0.00 & 204.28 & 12.92 & 13.25 & 0.03 \\
\hline Costa Rica & 0.10 & 679.22 & 13.22 & 12.53 & 0.05 \\
\hline Cyprus & 0.03 & 1164.83 & 14.26 & 13.37 & 0.06 \\
\hline Saudi Arabia & 154.28 & 715.41 & 74.00 & 80.13 & 0.08 \\
\hline Turkey & 0.26 & 963.20 & 12.06 & 11.05 & 0.08 \\
\hline El Salvador & 0.11 & 448.98 & 12.17 & 11.06 & 0.09 \\
\hline Pakistan & 0.15 & 324.08 & 8.17 & 8.99 & 0.10 \\
\hline Senegal & 0.00 & 159.62 & 14.75 & 13.01 & 0.12 \\
\hline Mexico & 10.40 & 711.92 & 10.56 & 9.28 & 0.12 \\
\hline Nigeria & 5.82 & 285.46 & 20.79 & 24.54 & 0.18 \\
\hline Yemen & 4.93 & 194.49 & 26.77 & 31.62 & 0.18 \\
\hline Slovakia & 0.68 & 1211.31 & 12.25 & 9.75 & 0.20 \\
\hline Sri Lanka & 0.01 & 505.44 & 11.10 & 13.37 & 0.21 \\
\hline Uganda & 0.00 & 147.94 & 15.95 & 12.53 & 0.21 \\
\hline Chile & 0.32 & 757.76 & 13.93 & 10.24 & 0.26 \\
\hline Trinidad and Tobago & 41.31 & 684.16 & 38.07 & 48.38 & 0.27 \\
\hline Honduras & 0.00 & 261.20 & 18.70 & 13.22 & 0.29 \\
\hline Kenya & 0.00 & 205.29 & 10.16 & 13.25 & 0.30 \\
\hline Nepal & 0.00 & 201.85 & 19.14 & 13.00 & 0.32 \\
\hline Poland & 0.32 & 1051.37 & 16.83 & 11.05 & 0.34 \\
\hline Paraguay & 0.09 & 448.61 & 18.41 & 11.64 & 0.37 \\
\hline Libya & 95.97 & 394.69 & 144.82 & 86.22 & 0.40 \\
\hline Uruguay & 0.11 & 780.58 & 21.47 & 12.53 & 0.42 \\
\hline Latvia & 0.13 & 978.38 & 22.04 & 12.63 & 0.43 \\
\hline Japan & 0.38 & 1434.98 & 21.06 & 11.63 & 0.45 \\
\hline Iceland & 0.00 & 1459.88 & 24.98 & 13.37 & 0.47 \\
\hline Czech Republic & 0.46 & 1340.32 & 20.72 & 11.06 & 0.47 \\
\hline Bosnia and Herzegovina & 0.00 & 522.70 & 26.32 & 13.37 & 0.49 \\
\hline Ethiopia & 0.00 & 81.39 & 7.35 & 11.07 & 0.51 \\
\hline Israel & 0.26 & 1216.59 & 24.17 & 11.79 & 0.51 \\
\hline Algeria & 19.23 & 453.73 & 86.12 & 41.48 & 0.52 \\
\hline Sweden & 0.33 & 1775.69 & 8.24 & 12.53 & 0.52 \\
\hline Zambia & 0.00 & 250.54 & 8.63 & 13.22 & 0.53 \\
\hline Morocco & 0.05 & 381.23 & 25.67 & 11.90 & 0.54 \\
\hline Korea, Republic of & 0.31 & 1147.71 & 25.21 & 11.66 & 0.54 \\
\hline Philippines & 0.11 & 395.97 & 25.37 & 10.94 & 0.57 \\
\hline Guatemala & 0.46 & 444.19 & 13.45 & 5.56 & 0.59 \\
\hline Belarus & 1.29 & 686.52 & 8.18 & 3.28 & 0.60 \\
\hline Lithuania & 1.08 & 1006.27 & 17.54 & 6.84 & 0.61 \\
\hline Afghanistan & 0.00 & 154.93 & 33.78 & 12.64 & 0.63 \\
\hline Switzerland & 0.17 & 2283.75 & 35.42 & 13.22 & 0.63 \\
\hline Slovenia & 0.03 & 1267.56 & 8.05 & 13.37 & 0.66 \\
\hline Panama & 0.00 & 653.59 & 8.02 & 13.37 & 0.67 \\
\hline Bulgaria & 0.17 & 759.36 & 35.32 & 11.63 & 0.67 \\
\hline Bangladesh & 0.01 & 250.95 & 7.73 & 13.00 & 0.68 \\
\hline Colombia & 5.74 & 622.26 & 10.24 & 3.18 & 0.69 \\
\hline India & 0.28 & 314.66 & 18.38 & 5.64 & 0.693 \\
\hline Jordan & 0.02 & 516.53 & 43.84 & 13.22 & 0.70 \\
\hline Jamaica & 0.48 & 393.01 & 15.64 & 4.40 & 0.72 \\
\hline Estonia & 2.46 & 1103.04 & 11.33 & 3.16 & 0.72 \\
\hline Cameroon & 1.40 & 210.86 & 11.61 & 3.16 & 0.73 \\
\hline Hungary & 1.28 & 1165.28 & 26.40 & 6.96 & 0.74 \\
\hline Italy & 0.98 & 1637.34 & 5.60 & 9.73 & 0.74 \\
\hline Netherlands & 1.55 & 1642.88 & 4.38 & 7.76 & 0.77 \\
\hline New Zealand & 3.89 & 1302.11 & 10.27 & 2.21 & 0.79 \\
\hline Macao & 0.00 & 4309.97 & 65.50 & 13.36 & 0.80 \\
\hline South Africa & 1.43 & 619.24 & 10.99 & 2.20 & 0.80 \\
\hline Botswana & 0.00 & 751.30 & 67.80 & 13.37 & 0.80 \\
\hline Ukraine & 0.73 & 464.00 & 19.13 & 3.51 & 0.82 \\
\hline
\end{tabular}


Table 6: Countries by Explanatory Power of Productivity and Oil Output (continued)

\begin{tabular}{|c|c|c|c|c|c|}
\hline & Oil per cap & Productivity & $\begin{array}{c}\text { Reserves } / G D P \\
(\text { data }, \%)\end{array}$ & $\begin{array}{c}\text { Reserves } / G D P \\
(\text { model }, \%)\end{array}$ & Gap \\
\hline Puerto Rico & 0.19 & 1214.77 & 6.74 & 12.52 & 0.86 \\
\hline Croatia & 1.98 & 962.79 & 23.20 & 3.28 & 0.86 \\
\hline Bolivia & 2.08 & 248.40 & 39.57 & 5.57 & 0.86 \\
\hline Hong Kong & 0.00 & 1782.51 & 95.21 & 13.37 & 0.86 \\
\hline Lebanon & 0.00 & 670.09 & 100.07 & 13.37 & 0.87 \\
\hline Congo, Dem. Rep. & 0.13 & 69.66 & 3.33 & 0.44 & 0.87 \\
\hline Serbia & 0.99 & 671.55 & 33.71 & 4.40 & 0.87 \\
\hline Bahrain & 16.83 & 1506.44 & 16.86 & 2.08 & 0.88 \\
\hline Malaysia & 9.89 & 802.48 & 47.17 & 5.80 & 0.88 \\
\hline Romania & 2.01 & 907.49 & 24.63 & 2.90 & 0.88 \\
\hline United Kingdom & 8.82 & 1640.56 & 2.73 & 0.28 & 0.90 \\
\hline Singapore & 1.22 & 1832.72 & 94.36 & 9.35 & 0.90 \\
\hline Egypt & 3.37 & 482.98 & 16.91 & 1.27 & 0.93 \\
\hline Albania & 1.24 & 485.48 & 19.68 & 1.42 & 0.93 \\
\hline Ghana & 0.46 & 213.96 & 13.53 & 0.96 & 0.93 \\
\hline Austria & 1.20 & 1826.28 & 4.84 & 9.35 & 0.93 \\
\hline Viet Nam & 1.50 & 262.62 & 17.23 & 1.03 & 0.94 \\
\hline Denmark & 18.97 & 1854.14 & 18.95 & 1.03 & 0.95 \\
\hline Brazil & 4.55 & 670.07 & 12.18 & 0.62 & 0.95 \\
\hline China & 1.13 & 495.22 & 42.26 & 1.69 & 0.96 \\
\hline Peru & 1.73 & 535.99 & 26.23 & 0.72 & 0.97 \\
\hline Indonesia & 1.65 & 448.57 & 12.44 & 0.28 & 0.98 \\
\hline United States & 11.32 & 1797.09 & 2.43 & 0.04 & 0.98 \\
\hline Thailand & 2.17 & 592.93 & 41.87 & 0.42 & 0.99 \\
\hline Tunisia & 2.70 & 547.23 & 18.82 & 0.03 & 1.00 \\
\hline Cote d'Ivoire & 0.92 & 244.59 & 12.38 & 0.00 & 1.00 \\
\hline Australia & 9.46 & 1484.94 & 4.41 & 0.00 & 1.00 \\
\hline Dominican Republic & 0.01 & 563.17 & 6.37 & 13.37 & 1.10 \\
\hline Iraq & 28.96 & 275.51 & 32.58 & 72.00 & 1.21 \\
\hline Germany & 0.72 & 1771.89 & 4.86 & 10.94 & 1.25 \\
\hline France & 0.44 & 1635.00 & 4.82 & 11.63 & 1.41 \\
\hline Finland & 0.75 & 1612.32 & 4.25 & 10.97 & 1.58 \\
\hline Belgium & 0.36 & 1507.99 & 4.39 & 11.79 & 1.68 \\
\hline Kazakhstan & 34.05 & 582.77 & 16.85 & 48.48 & 1.88 \\
\hline Congo & 24.58 & 139.00 & 28.20 & 86.50 & 2.07 \\
\hline Oman & 108.24 & 1020.95 & 18.93 & 58.18 & 2.07 \\
\hline Norway & 184.95 & 2081.49 & 13.31 & 48.02 & 2.61 \\
\hline United Arab Emirates & 179.57 & 1869.36 & 13.52 & 50.80 & 2.76 \\
\hline Venezuela & 35.18 & 531.01 & 12.87 & 52.31 & 3.06 \\
\hline Angola & 32.73 & 204.66 & 20.37 & 83.51 & 3.10 \\
\hline Azerbaijan & 32.74 & 374.91 & 13.62 & 62.89 & 3.62 \\
\hline Qatar & 427.64 & 2170.10 & 14.29 & 67.71 & 3.74 \\
\hline Kuwait & 359.56 & 1143.66 & 17.03 & 80.85 & 3.75 \\
\hline Brunei Darussalam & 164.44 & 1438.42 & 10.98 & 57.04 & 4.19 \\
\hline Spain & 0.25 & 1437.10 & 2.17 & 12.53 & 4.78 \\
\hline Canada & 37.67 & 1377.98 & 3.35 & 19.50 & 4.83 \\
\hline Gabon & 60.50 & 477.58 & 11.33 & 72.55 & 5.40 \\
\hline Ecuador & 12.81 & 392.57 & 4.86 & 32.65 & 5.72 \\
\hline Greece & 0.22 & 1234.33 & 1.66 & 12.53 & 6.53 \\
\hline Sudan & 4.09 & 209.56 & 2.80 & 24.19 & 7.64 \\
\hline Luxembourg & 0.00 & 2819.47 & 1.18 & 13.37 & 10.31 \\
\hline Ireland & 0.04 & 1916.90 & 0.71 & 13.37 & 17.88 \\
\hline
\end{tabular}

This table lists 112 countries with their oil production per capita per year, productivity and reserves-to-GDP ratio in the data (data ratios), along with the reserves-to-GDP ratio generated by the structural model (model ratios). The "Gap" metric measures the absolute value of the percentage deviation of the model ratio from the data ratio. 
Table 7: Distribution of Countries in Terms of the Gap

\begin{tabular}{l|cc|cc}
\hline \hline Gap & \#of countries & fraction & $\begin{array}{c}\text { \#of countries } \\
\text { (cumulative) }\end{array}$ & $\begin{array}{c}\text { fraction } \\
\text { (cumulative) }\end{array}$ \\
\hline$\leq 0.25$ & 15 & 0.134 & 15 & 0.134 \\
$>0.25, \leq 0.5$ & 14 & 0.125 & 29 & 0.259 \\
$>0.5, \leq 0.75$ & 25 & 0.223 & 54 & 0.482 \\
$>0.75, \leq 1.0$ & 33 & 0.295 & 87 & 0.777 \\
$>1.0, \leq 3.0$ & 11 & 0.098 & 98 & 0.875 \\
$>3.0$ & 14 & 0.125 & 112 & 1.000 \\
\hline \hline
\end{tabular}

This table summarizes the distribution of countries in terms of the gap which is defined as the absolute value of percentage deviation of the reserves-to-GDP ratio generated by the structural model (model ratio) from the data ratio. A larger gap implies lower explanatory power of oil production and productivity with respect to the reserves-to-GDP ratio.

Table 8: Explanatory Power of Conventional Variables

\begin{tabular}{l|cc}
\hline \hline Gap & $R^{2}$ & Adjusted $R^{2}$ \\
\hline$\leq 0.25$ & 0.321 & 0.050 \\
$>0.25, \leq 0.5$ & 0.384 & 0.226 \\
$>0.5, \leq 0.75$ & 0.328 & 0.148 \\
$>0.75, \leq 1.0$ & 0.756 & 0.721 \\
$>1.0, \leq 3.0$ & 0.693 & 0.599 \\
$>3.0$ & 0.892 & 0.837 \\
\hline \hline
\end{tabular}

This table reports the $R^{2}$ and adjusted $R^{2}$ from the residual regressions where the difference in the reserves-to-GDP ratio between the model and the data is regressed on the set of variables used in the fixed effect regressions, excluding productivity and oil production. 
Table 9: Results of Residual Regressions

\begin{tabular}{l|cc|cc|cc|cc|cc|cc}
\hline \hline \multicolumn{1}{c|}{ Gap } & \multicolumn{2}{c|}{$\leq 0.25$} & \multicolumn{2}{c|}{$>0.25, \leq 0.5$} & \multicolumn{2}{c|}{$>0.5, \leq 0.75$} & \multicolumn{2}{c|}{$>0.75, \leq 1.0$} & \multicolumn{2}{c|}{$>1.0, \leq 3.0$} & \multicolumn{2}{c}{$>3.0$} \\
\hline & Coef. & t-stat & Coef. & t-stat & Coef. & t-stat & Coef. & t-stat & Coef. & t-stat & Coef. & t-stat \\
\hline Trade/GDP & 0.01 & 0.28 & 0.26 & 3.23 & 0.22 & 1.18 & 0.21 & 1.47 & -0.69 & -5.31 & -0.80 & -6.69 \\
Import/GDP & -0.06 & -0.76 & -0.51 & -3.16 & -0.38 & -0.98 & 0.11 & 0.36 & 1.82 & 6.32 & 1.78 & 5.78 \\
Short-debt/GDP & 0.00 & -0.05 & -0.01 & -1.02 & -0.02 & -1.20 & -0.01 & -0.94 & -0.05 & -2.70 & 0.09 & 3.14 \\
Capital Openness & -0.50 & -0.45 & -5.55 & -3.11 & -13.71 & -3.29 & -12.16 & -4.88 & 3.02 & 0.82 & -3.98 & -0.79 \\
FDI/GDP & -0.01 & -0.36 & -0.02 & -0.56 & 0.08 & 0.99 & -0.04 & -1.16 & 0.00 & 0.01 & 0.12 & 2.25 \\
M2/GDP & 0.01 & 0.57 & 0.04 & 3.25 & -0.02 & -0.48 & 0.03 & 1.61 & 0.09 & 4.31 & 0.03 & 1.07 \\
FX volatility & 0.14 & 1.13 & 0.04 & 0.18 & 0.14 & 0.16 & -1.28 & -2.92 & 0.24 & 0.90 & 0.59 & 1.42 \\
GDPgrowth & -0.02 & -0.24 & 0.41 & 2.26 & 0.28 & 0.64 & 0.09 & 0.42 & 0.36 & 1.41 & -0.34 & -1.05 \\
Export Volatility & 0.00 & -0.02 & 0.21 & 0.67 & 0.80 & 1.24 & 0.80 & 1.93 & -1.94 & -4.35 & -4.78 & -6.86 \\
Agri-imports/GDP & 0.36 & 1.50 & 0.58 & 1.32 & 1.06 & 1.04 & -4.46 & -7.17 & -0.93 & -1.23 & -2.66 & -2.04 \\
\hline \hline
\end{tabular}

This table reports the coefficients and t-statistics from the residual regressions where the difference in the reserves-to-GDP ratio between the model and the data is regressed on the set of variables used in the fixed effect regressions, excluding productivity and oil production. 
Figure 1: Policy Functions
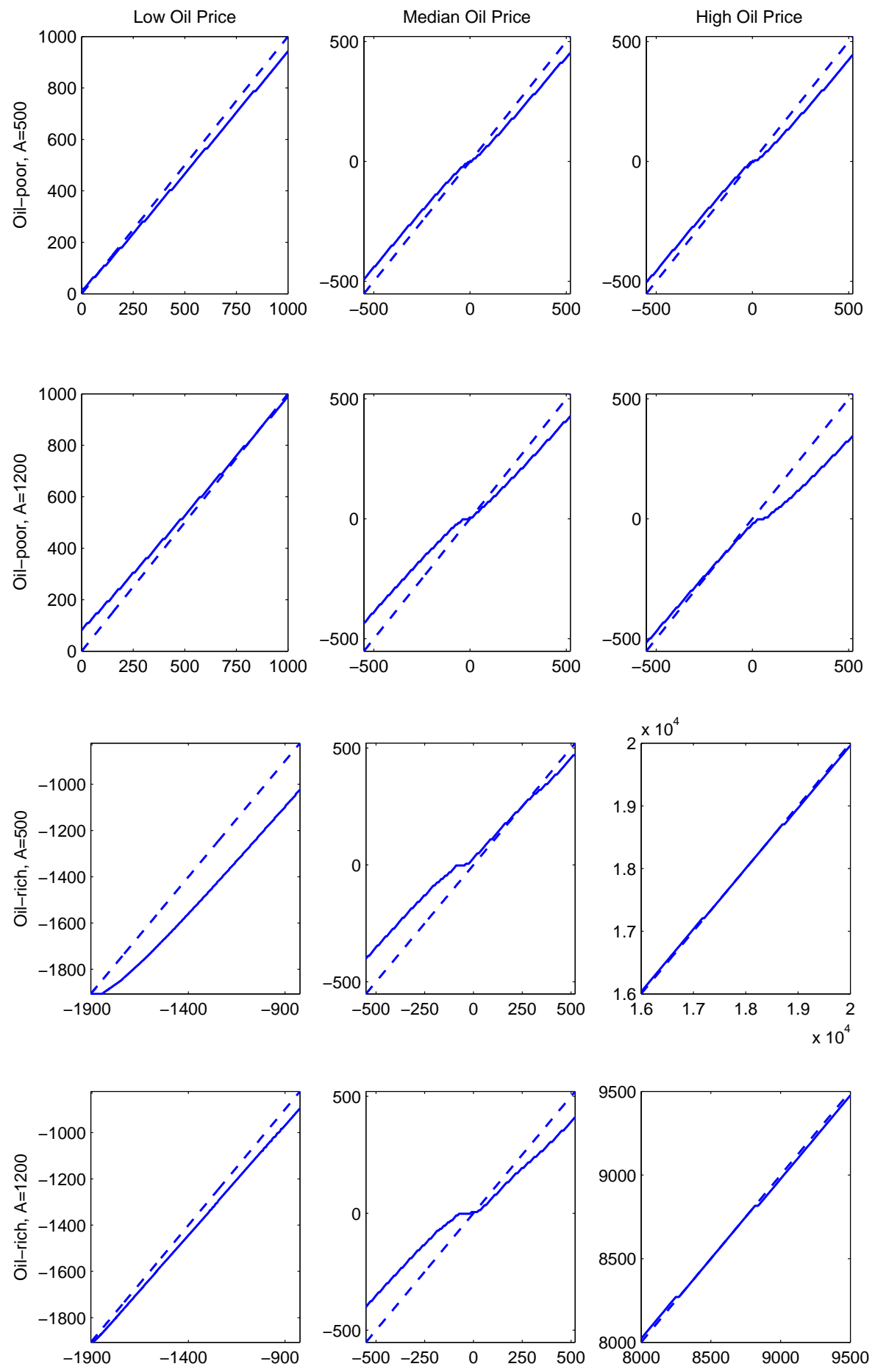

The solid lines show policy functions of the four combinations of productivity and oil output. The horizontal axis represents the foreign reserves in the beginning of a period in terms of 2006 USD per person, and the vertical axis represents the reserves in the end of a period. The dashed line is the 45 -degree line. 


\section{Appendices}

\section{A The re-scaling of non-stationary variables}

Let $G_{A}$ be the growth factor of both productivity and oil price, this appendix shows that

(1) Foreign reserves, GDP and consumption have the growth factor of $G_{A}$

(2) Value function has the multiplicative scaling property:

$$
V(s, p, A, \bar{x})=G_{A}^{1-\gamma} V\left(\frac{s}{G_{A}}, \frac{p}{G_{A}}, \frac{A}{G_{A}}, \bar{x}\right)
$$

(3) The dynamic programming problem in Section 2.4 can be solved using detrended productivity and oil price.

Based on the contraction mapping theorem, one can start from an arbitrary initial value function, and keep iterating the the functional equation (13) to reach the fixed point. We start from the simple initial guess that assumes zero future value. That is

$$
\begin{aligned}
V^{0}(s, p, A, \bar{x}) & =\max _{s^{\prime}} \frac{c^{1-\gamma}}{1-\gamma} \\
\text { s.t. } & \\
c & =s-\frac{s^{\prime}}{1+r}+A x^{\alpha}-p x^{i m}
\end{aligned}
$$

where $x=\bar{x}+x^{i m}$.

Clearly, the optimal solution is $s^{\prime}=0$, and we have

$$
\begin{aligned}
V^{0}(s, p, A, \bar{x}) & =\frac{1}{1-\gamma}\left(s+A x^{\alpha}-p x^{i m}\right)^{1-\gamma} \\
& =G_{A}^{1-\gamma} \frac{1}{1-\gamma}\left(\frac{s}{G_{A}}+\frac{A}{G_{A}} x^{\alpha}-\frac{p}{G_{A}} x^{i m}\right)^{1-\gamma} \\
& =G_{A}^{1-\gamma} V^{0}\left(\frac{s}{G_{A}}, \frac{p}{G_{A}}, \frac{A}{G_{A}}, \bar{x}\right) .
\end{aligned}
$$

That is, foreign reserves can by re-scaled by $G_{A}$, and the initial guess of value function satisfies Equation (20). Consumption can also be re-scaled by $G_{A}$ based on the budget constraint. 
Next we iterate the functional equation forward to obtain

$$
\begin{aligned}
& V^{1}(s, p, A, \bar{x})=\max _{s^{\prime}}\left\{\frac{1}{1-\gamma}\left(s-\frac{s^{\prime}}{1+r}+A x^{\alpha}-p x^{i m}\right)^{1-\gamma}+\beta E V^{0}\left(s^{\prime}, A^{\prime}, p^{\prime}\right)\right\} \\
= & \max _{s^{\prime}}\left\{\frac{1}{1-\gamma}\left(s-\frac{s^{\prime}}{1+r}+A x^{\alpha}-p x^{i m}\right)^{1-\gamma}+\beta G_{A}^{1-\gamma} E V^{0}\left(\frac{s^{\prime}}{G_{A}}, \frac{A^{\prime}}{G_{A}}, \frac{p^{\prime}}{G_{A}}\right)\right\} \\
= & G_{A}^{1-\gamma} \max _{s^{\prime} / G_{A}}\left\{\frac{1}{1-\gamma}\left(\frac{s}{G_{A}}-\frac{s^{\prime}}{G_{A}(1+r)}+\frac{A}{G_{A}} x^{\alpha}-\frac{p}{G_{A}} x^{i m}\right)^{1-\gamma}+\beta E V^{0}\left(\frac{s^{\prime}}{G_{A}}, \frac{A^{\prime}}{G_{A}}, \frac{p^{\prime}}{G_{A}}\right)\right\} \\
= & G_{A}^{1-\gamma} V^{1}\left(\frac{s}{G_{A}}, \frac{p}{G_{A}}, \frac{A}{G_{A}}, \bar{x}\right),
\end{aligned}
$$

i.e. $V^{1}$ also satisfies Equation 200. We can keep the above backward induction process until the value function converges. Thereby we conclude the value function always satisfies Equation 20).

In the above analysis, foreign reserves and consumption are always re-scaled by $G_{A}$. In other words, foreign reserves and consumption have the growth factor of $G_{A}$. Using Equation (6), it is straightforward to see that the growth factor of GDP is also $G_{A}$ given that both productivity and oil price grow at the factor of $G_{A}$.

Define $\tilde{p}^{\prime}=\frac{p^{\prime}}{G_{A}}, \tilde{A}^{\prime}=\frac{A^{\prime}}{G_{A}}, \tilde{s}^{\prime}=\frac{s^{\prime}}{G_{A}}, \tilde{c}^{\prime}=\frac{c^{\prime}}{G_{A}}$ and $\tilde{V}(\tilde{s}, \tilde{p}, \tilde{A}, \bar{x})=G_{A}^{1-\gamma} V(s, p, A, \bar{x})$. Using these detrended variables, the dynamic programming can be re-written as

$$
\begin{aligned}
\tilde{V}(\tilde{s}, \tilde{p}, \tilde{A}, \bar{x}) & =\max _{\tilde{s}^{\prime}}\left\{u(\tilde{c})+\beta E \tilde{V}\left(\tilde{s}^{\prime}, \tilde{p}^{\prime}, \tilde{A}^{\prime}, \bar{x}\right)\right\} \\
\text { s.t. } & \\
\tilde{c} & =\tilde{s}-\frac{\tilde{s}^{\prime}}{1+r}+\tilde{A} x^{\alpha}-\tilde{p} x^{i m} .
\end{aligned}
$$

Thereby we transform the non-stationary dynamic programming problem into a stationary one in which none of the state variable or control variable has a growing trend.

In the transformed problem, productivity is a constant over time. To compute the problem, for each pair of $(\tilde{A}, \bar{x})$, we define a state space of $(\tilde{s}, \tilde{p})$ with $\tilde{s}$ proxied by 300 grid points and $\tilde{p}$ proxid by three states as shown in section 3.2 .2 , and iterate the value function on the state space until it converges. Given the converged value function, we compute the policy function on the $(\tilde{s}, \tilde{p})$ space for each pair of $(\tilde{A}, \bar{x})$. Simulated data are generated using these policy functions. 


\section{B Data Description and Sources}

The fixed effect regressions are based on a sample of 54 countries (regions) between 19932013. We exclude countries that have extreme observations of reserves-to-GDP ratios or GDP growth rates. For example, Libya's reserves/GDP was 318.56 in 2011. Extreme GDP growth rates are observed in Libya $(-62.1 \%$ in 2011, $104.5 \%$ in 2012), , Bosnia and Herzegovina (89.0\% in 1996 and $34.4 \%$ in 1997), and Iraq (-33.1\% in 2003 and $54.2 \%$ in 2004). We also exclude countries that experienced extreme exchange rate volatility and short term debt. Also data regarding productivity, reserves and oil output are severely missing for some countries, such as Argentina, Cuba, Iran, Iraq, Puerto Rico, Uzbekistan, and Jamaica. These countries are also excluded in the sample. In total we have 940 observations of countries from different years.

The following countries (regions) are included in the fixed effect regressions: Australia, Austria, Belgium,, Bulgaria, Brazil, Canada, Switzerland, Chile, China, Cameroon, Colombia, Costa Rica, Cyprus, Czech Republic, Germany, Denmark, Dominican Republic, Algeria, Ecuador, Spain, Finland, France, United Kingdom, Ghana, Greece, Croatia, Hungary, Ireland, Iceland, Israel, Italy, Japan, Latvia, Morocco, Mexico, Malaysia, Nigeria, Netherlands, Norway, Pakistan, Philippines, Poland, Portugal, Romania, Russian Federation, Singapore, Sweden, Tunisia, Ukraine, Uruguay, United States, Venezuela, South Africa, Congo. We also analyze a sample of 112 countries with shorter time period (2003-2013) in section 4. These countries are listed in Tables 5. 6.

Annual oil price index is from United Nations Conference on Trade and Development (UNCTAD), available at http://unctadstat.unctad.org/wds/TableViewer/tableView. aspx?ReportId=30727. We use the price index of crude petroleum which is the average of UK Brent (light), Dubai (medium) and Texas (heavy), equally weighted. To estimate the $\mathrm{AR}(1)$ process of oil price, we first take logarithm of oil price index and denote it $\log (p)$, then detrend $\log (p)$ using the Hodrick-Prescott filter. The detrended $\log (p)$ is then regressed on its lag, as in Equation (17).

Data on foreign reserves, GDP and other macroeconomic variables are obtained from World Development Indicators database of the World Bank, except for foreign direct invest- 
ments (FDI) and real exchange rates. Data on FDI are from United Nations Conference on Trade and Development(UNCTAD). Real Effect Exchange Rate indices are from International Financial Statistics provided by the IMF. Oil production data are from International Energy Statistics collected by U.S. Energy Information Administration.

\section{Estimating Oil Share in Production $(\alpha)$ and Produc- tivity (A)}

We estimate the share of oil in production function and country-specific productivity based on the production $y_{t}=A_{t} \times x_{t}^{\alpha}$. Recall that $A_{t}$ is the comprehensive measure of how efficient a country is in converting natural resources into final good, and $x_{t}=\bar{x}+x_{t}^{i m}$ is the per capita natural resource consumed by a country in period $t$.

\section{C.1 Estimating $\alpha$}

The production function can be rewritten as

$$
\log y_{t}=\log A_{t}+\alpha \times \log \left(x_{t}\right)
$$

Denote

$$
\begin{aligned}
g_{y t} & =\frac{y_{t}}{y_{t-1}} \\
g_{A t} & =\frac{A_{t}}{A_{t-1}} \\
g_{x t} & =\frac{x_{t}}{x_{t-1}}
\end{aligned}
$$

Then,

$$
\log \left(g_{y t}\right)=\log \left(g_{A t}\right)+\alpha \times \log \left(g_{x t}\right)
$$

In our model, volatility of the economy comes from random shocks to oil price, rather than from TFP shocks. Thus it is reasonable to assume that $g_{A t}$ has no cyclical movement. On the other hand, both $g_{x t}$ and $g_{y t}$ response to oil price shocks endogenously. Therefore, we can regress $\log \left(g_{y t}\right)$ on $\log \left(g_{x t}\right)$ to estimate $\alpha$. 
For each country, we use the growth rate of real GDP as a proxy for $g_{y t}$, and the growth of oil consumption per capita as a proxy for $g_{x t}$. Pooling data from all countries in the sample, we run Equation (22) and obtain $\hat{\alpha}=0.2369$.

\section{C.2 Estimating Productivity}

Plugging this estimated $\alpha$ into (21) and re-arranging the equation, we have the following equation:

$$
\log \left(A_{t}\right)=\log \left(y_{t}\right)-0.2369 \times \log \left(x_{t}\right)
$$

Equation (23) is used to calculate country-specific $A_{t}$. We use the annual oil consumption per person in terms of barrels for $x_{t}$, and use GDP per capita in terms of US dollars in year 2006 for $y_{t}{ }^{27}$ The estimated country-specific productivity is used to estimate Equation (15) and to obtain the partial effects of productivity on reserves-to-GDP ratio.

\section{Market return of foreign reserves}

The market return is the opportunity cost of foreign reserves. According to COFER (Currency Composition of Official Foreign Exchange Reserves) data, US Dollar nominated assets consist of respectively $70 \%$ of the international reserves for developed country and developing countries hold somewhat fewer dollars. Gold is the main reserves for USA, Germany, Italy and France, but has limited share in the reserves of other country. In the period from 1981 to 2010, the related assets has following return: 1) US Treasury bond: CMT (Constant Maturity Treasury) index is the bench mark rate for US bonds and its return is $5.65 \%$ in this period. 2) Dollar deposit: according to Robert Shiller, the one-year deposit rate was $1.03 \% \sqrt{{ }^{28}}$ 3) Dollar cash: the growth of CPI is $3.5 \%$ hence the return for hold dollar cash is $-3.5 \%$. 4) gold: according to Commodity Price Data and Statistics by World Bank, the yearly return of holding gold is $1.78 \%$.

If a country holds its reserves among gold, US Treasury bond, dollar deposit and dollar cash evenly, the real return will be $1.2 \%$. If gold, US Treasury bond, dollar deposit take

\footnotetext{
${ }^{27}$ Correspondingly, average oil price used in the structural estimation is also in terms of 2006 US dollars.

${ }^{28}$ Data available at http://www.econ.yale.edu/ shiller/data.htm
} 
$30 \%$, dollar cash $10 \%$, the return will be $2.18 \%$.

Table A1: Summary Statistics

\begin{tabular}{rcccccccc}
\hline \hline Variable & \# of obs. & Mean & S.D. & Min & 0.25 & Median & 0.75 & Max \\
\hline Reserves/GDP (\%) & 940 & 15.23 & 15.98 & 0.10 & 5.52 & 11.00 & 19.87 & 113.05 \\
Oil Output per cap & 940 & 6.82 & 20.72 & 0.00 & 0.14 & 0.83 & 5.13 & 261.7 \\
Oil consumption per cap & 940 & 7.55 & 9.88 & 0.05 & 2.05 & 4.58 & 10.84 & 85.62 \\
Productivity & 940 & 895.4 & 624.2 & 65.4 & 402.7 & 678.4 & 1450.3 & 2607.8 \\
Trade/GDP & 940 & 76.83 & 48.96 & 14.93 & 50.44 & 67.23 & 89.78 & 439.66 \\
Import/GDP & 940 & 38.16 & 22.96 & 7.91 & 24.31 & 33.03 & 45.34 & 209.39 \\
Agri-import/GDP & 940 & 3.32 & 1.64 & 0.49 & 2.13 & 3.04 & 4.18 & 11.93 \\
Short-debt/GDP & 940 & 35.78 & 73.39 & 0.00 & 4.09 & 8.11 & 28.34 & 485.34 \\
KA Openness & 940 & 0.6 & 0.37 & 0.00 & 0.16 & 0.70 & 1 & 1 \\
FDI/GDP & 940 & 36.03 & 34.85 & 0.21 & 14.56 & 27.91 & 45.00 & 281.15 \\
M2/GDP & 940 & 70.40 & 52.09 & 1.62 & 31.46 & 54.65 & 97.04 & 283.40 \\
Exchange volatility & 940 & 4.62 & 35.18 & 0.24 & 1.15 & 1.94 & 3.42 & 1016.16 \\
GDP growth & 940 & 3.38 & 3.91 & -17.95 & 1.6 & 3.63 & 5.33 & 33.74 \\
Export volatility & 940 & 4.50 & 3.10 & 0.51 & 2.27 & 3.82 & 5.89 & 22.8 \\
\hline \hline
\end{tabular}


Table A2: Oil Output and Oil Trade

\begin{tabular}{c|c|c}
\hline & Oil-poor countries & Oil-rich countries \\
\hline Oil importers & $\begin{array}{c}0.641 \\
(0.019)\end{array}$ & $\begin{array}{c}0.034 \\
(0.011)\end{array}$ \\
\hline Oil exporters & $\begin{array}{c}0.056 \\
(0.009)\end{array}$ & $\begin{array}{c}0.269 \\
(0.019)\end{array}$ \\
\hline
\end{tabular}

This table reports the probability distribution of countries in the two-by-two space of oil trading and oil production. Standard errors are reported in the parenthesis. 